\title{
The dynamics of human capital accumulation in the ex-communist countries in Europe in the context of globalization
}

\author{
Victor Marian Dumitrache ${ }^{1, *}$, Svetlana Platagea Gombos ${ }^{1}$, Florina Bran and Petronela \\ Evelina Balu ${ }^{1}$ \\ ${ }^{1}$ The Bucharest University of Economic Studies, PhD student, Piata Romana nr. 6, 010374, Bucharest, \\ Romania
}

\begin{abstract}
.
Research background: Countries with a similar background before 1990, in the communist bloc in Europe, have begun since the ' 90 s to differentiate one from another in terms of development. Nowadays, in many aspects of the socio-economic environment, including welfare and labor productivity, the gaps between them are significant. Measurements done by World Bank Group through The Human Capital Project give us the opportunity to compare the achievements from the last 30 years of the ex-communist countries building strong democracies and open markets.

Purpose of the article: The purpose of this paper is to identify the major gaps between $8 \mathrm{EU}$ ex-communist countries in terms of human capital accumulation in the context of globalization - and the way the globalization fostered or suppressed the human development and human capital accumulation.

Methods: We will do a comparative analysis of the indicators that the Human Capital Project are based on - life expectancy, expected years of schooling, quality of education and GDP/capita of the $8 \mathrm{EU}$ ex-communist countries.

Findings \& Value added: This paper may add value to the economic and educational policies in the $8 \mathrm{EU}$ ex-communist countries by identifying the policies that proved their effectiveness in generating higher labor productivity, policies that can be adapted and then adopted by the UE excommunist countries that are less developed.
\end{abstract}

Keywords: human capital accumulation; human capital development; globalization; ex-communist countries in Europe

JEL Classification: $O 15 ; J 24 ; F 63 ; I 15 ; I 25$

*Corresponding author: victor.dumitrache@gmail.com 


\section{Introduction}

Human capital consists of the knowledge, skills, and health that people accumulate throughout their lives, enabling them to realize their potential as productive members of society [1-4]. We can end extreme poverty and create societies that are more inclusive by developing human capital. This requires investment in people through nutrition, health care, quality education, jobs and skills.

The investment in human capital is also, among others, the only way to take advantage of the knowledge-based economy opportunities [5]. To make the best out of these opportunities is for the developing countries the faster way to grow their economies.

Closely related to technology are the education, knowledge, skills, and know-how of the workforce acquired at school, at home or at work. We are much more productive than a century ago not only because of the better technologies we have, but especially because of the richer know-how that the workforce has. But these skills refer to more than just the ability to handle machines. The education and know-how of the workforce are those that generate the scientific knowledge on which our progress is built, and which facilitates the adaptation and adoption of these technologies in various branches of the economy. [3]

Bassanini and Scarpetta [6] showed in a series of OECD data from 1971 to 1998 that increasing the duration of schooling by one year leads to an increase of $6 \%$ in GDP per capita. Benhabib and Spiegel [7] revealed that the introduction of human capital as a factor of production by function type Coob-Douglas leads to its insignificant effect on growth of GDP per capita, but if taken into account the influence of human capital on total factor productivity, the effects are visible in two aspects (E. Pelinescu 2015): a) human capital influences the internal rate of innovation as evidenced by Romer [8]; b) human capital influences the rate of diffusion of technology in the spirit demonstrated by Nelson and Phelps [9]. They show that an increase of $1 \%$ of the capital stock leads to a $0.13 \%$ increase in the rate of growth and the process of catching up technological development of other countries is strongly influenced by human capital stock nationwide as demonstrated by the Funke and Strulik [6].

Even though human capital is a central driver of sustainable growth and poverty reduction, policy makers sometimes find it hard to make the case for human capital investments [11-15]. After all, the benefits of investing in people can take a long time to materialize [16]. Building roads and bridges can generate quick economic-as well as political-benefits $[17,18]$. But investing in the human capital of young children will not deliver economic returns until those children grow up and join the workforce. [4, 19]

After the fall of communism, early ' 90 s to mid-2000, by opening their borders, the excommunist countries opened their labour market at European and global level. Many talents emigrated especially to western Europe to fulfil their potential. [20]

Most of the ex-communist countries, starting their transition to full democracy and market economy back in the early ' $90 \mathrm{~s}$, needed to find ways to retain and develop their human capital, to be competitive on the global education market and on the labour market, to stay attractive for their citizens and to become for foreigners. What they have accomplished in the field of human capital development (education + healthcare) in the past 30 years of transition is reflected in the Human Capital Index (HCI).

The Human Capital Index (HCI) helps us realize that GDP per worker could be, for example, 40 percentage points higher in Romania (fig. 1) if the country reached benchmarks of complete education and full health. HCI shows how the amount and the quality of education and healthcare that citizen of a country benefit of will increase the productivity of the country's human capital.

The purpose of this paper is to point out the major differences between $8 \mathrm{EU}$ excommunist countries - Bulgaria, Croatia, Czech Republic, Hungary, Poland, Romania 
Slovenia, and Slovakia - in terms of human capital development in the context of globalization. We considered that is more relevant to compare these 8 countries that share similar background before the '90s, that entered capitalism and democracy almost in the same period of time and that are all part of the European Union at this moment.

\section{Methods}

The current comparative analysis among the $8 \mathrm{EU}$ ex-communist countries relies on:

a) Human Capital Index raw data that can be found in the World Bank data catalogue [21]. The Human Capital Index (HCI) database provides data at the country level for each of the components of the Human Capital Index as well as for the overall index, disaggregated by gender. The index measures the amount of human capital that a child born today can expect to attain by age 18 , given the risks of poor health and poor education that prevail in the country where she lives. It is designed to highlight how improvements in current health and education outcomes shape the productivity of the next generation of workers, assuming that children born today experience over the next 18 years the educational opportunities and health risks that children in this age range currently face.

b) World Development Indicators database, World Bank, Eurostat-OECD PPP Programme for 2018 GDP/capita PPP [22]. Eurostat for 2018 public expenditure (\%GDP) on education and on healthcare in each of the $8 \mathrm{EU}$ ex-communist countries.

Considering that the latest Human Capital Index was calculated in 2018, all the other data (GDP/capita and public expenditure on education and healthcare as \%GDP, are all from 2018 to assure comparability.

The gaps between the 8 countries relative to their general Human Capital Index, to quality of education and to life expectancy are represented through histograms.

Also scatter plots were used to show the relation between variables like GDP/capita PPP and public expenditure on one hand and quality of education and life expectancy on the other hand. The end point of the analysis was not to find correlation between these variables, as data from only 8 countries were not statistically relevant, but to point out the major gaps between the 8 countries.

\section{Results}

Based on Human Capital Index (HCI), the 8 countries, with scores ranging from 0.60 (Romania) to 0.79 (Slovenia) (fig. 1), can be divided in 2 general categories:

- By income group, where Romania, Bulgaria and Croatia are together part of the upper middle-income group while the others (Slovak Republic, Hungary, Poland, Czech Republic, and Slovenia) are part of the high-income group (fig.2)

- By quartile of the HCI they belong to, where Romania, Bulgaria and Slovak Republic are part of the $2^{\text {nd }}$ quartile, while the others (Hungary, Croatia, Poland, Czech Republic, and Slovenia) are part of the $1^{\text {st }}$ quartile out of 157 countries. 


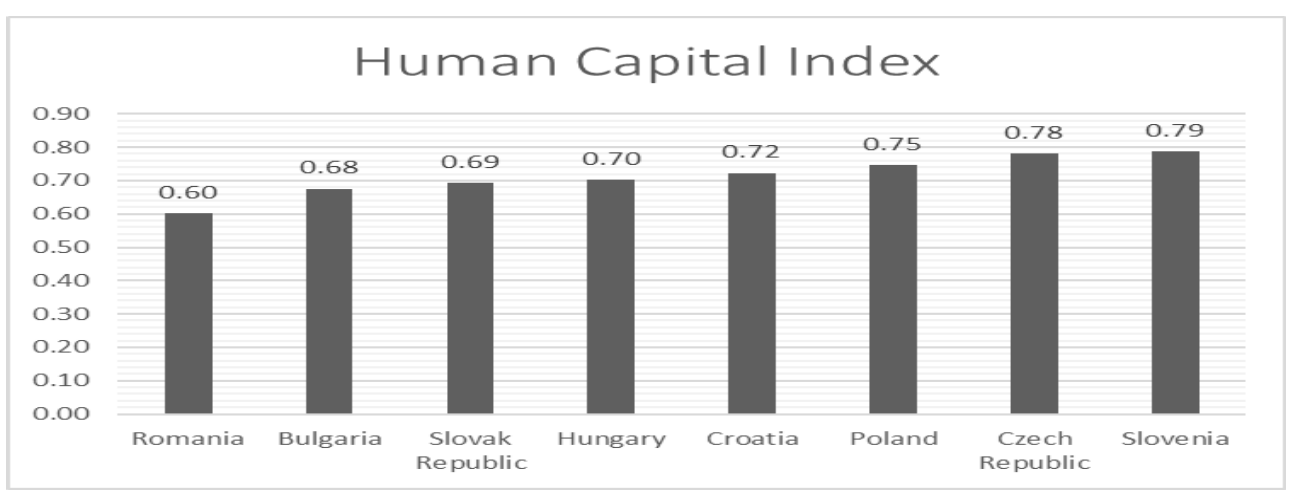

Fig. 1. Human Capital Index, 2018, of the 8 EU ex-communist countries

Based on the countries' income and quartile they belong to, we can notice that Slovak Republic is the only high-income country placed in the $2^{\text {nd }}$ quartile of HCI showing on average, lower performance than other countries from its income group. Similarly, we noticed Croatia which is the only country from upper middle-income group which is placed in the $1^{\text {st }}$ quartile of HCI showing, in average, higher performance than other countries from its income group.

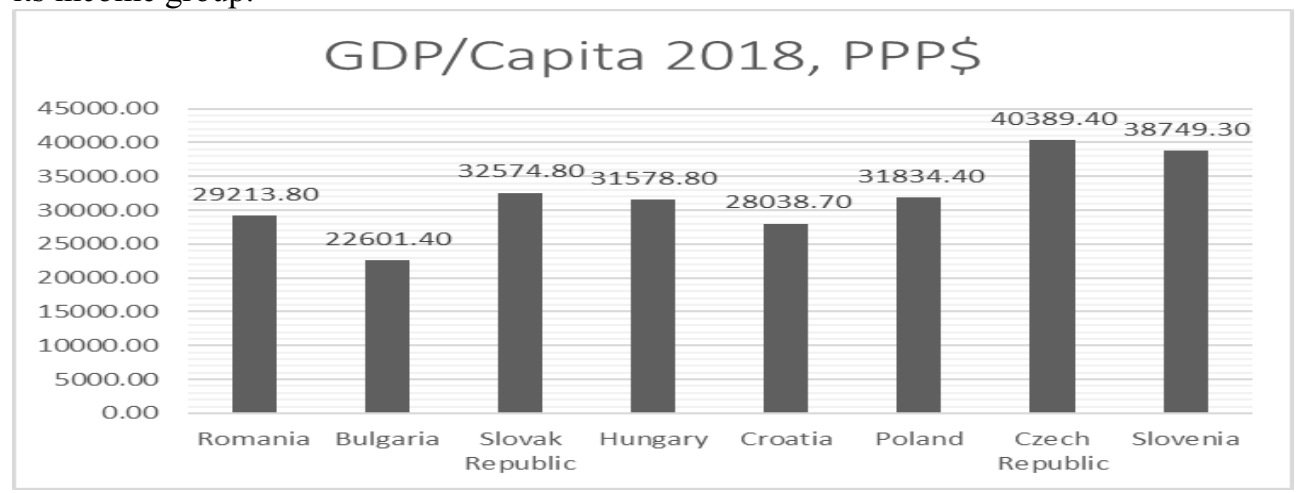

Fig. 2. Human Capital Index, 2018, of the 8 EU ex-communist countries

The survival dimension of HCI is measured through the probability of survival to the age of 5 which is similar among the 8 countries, Romania, Bulgaria and Slovak Republic having a score of 0.99 indicating a slightly higher child mortality rate comparing to the other 5 countries that have a score of 1.0

Healthcare dimensions is measured through adult survival rate in HCI. It measures the fraction of the 15 -year-olds who survive to age 60 . In the case of the 8 countries, this rate ranges from 0.87 (Romania, Bulgaria, Hungary) to 0.93 (Slovenia) (fig. 3). 


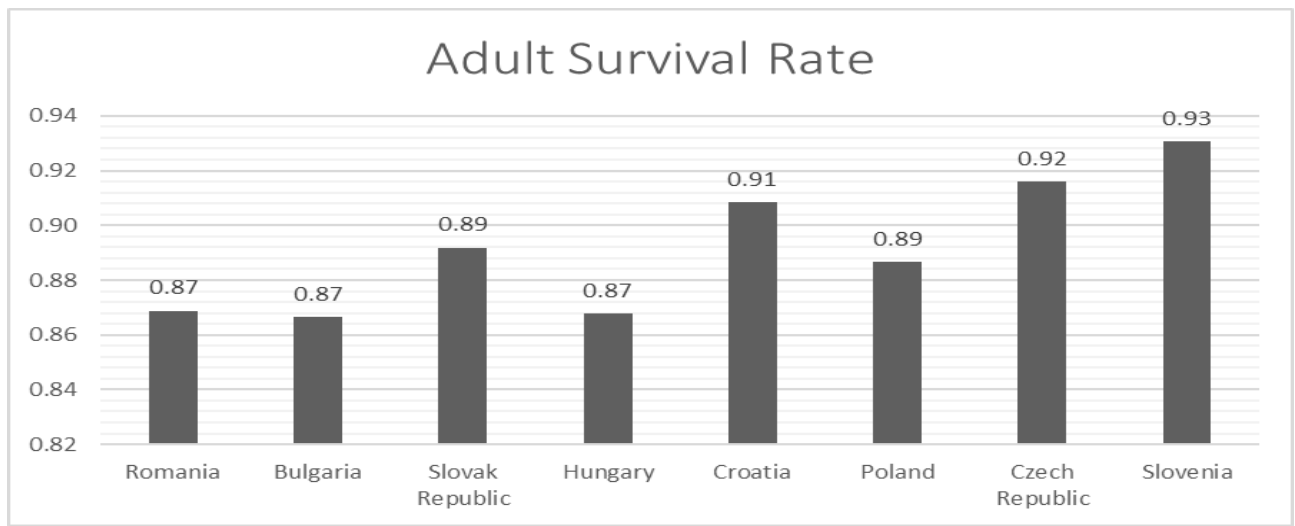

Fig. 3. Adult survival rate, 2018 , of the $8 \mathrm{EU}$ ex-communist countries

When corelating the Adult Survival Rate with the GDP/capita (fig. 4) and with public expenditure on healthcare as \%GDP (fig. 5), we notice that healthcare expenditure of Slovenia and Croatia (6.6\% each) has the highest return on the adult survival rate, these countries being the high performers in healthcare relative to their income and allocation on healthcare. Also, we notice Hungary having the lowest performance relative to its income and allocation on healthcare.

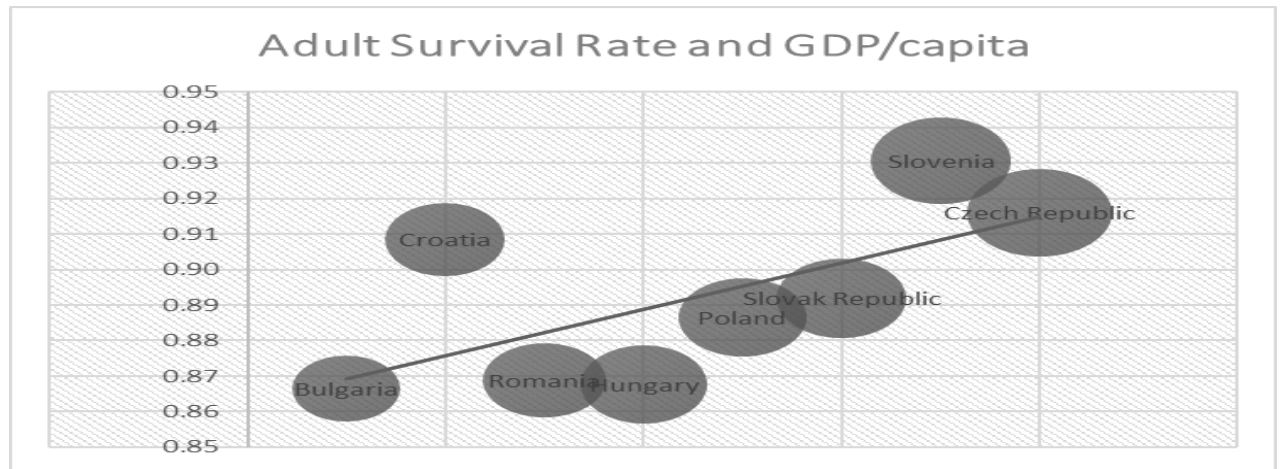

Fig. 4. The relation between GDP/capita and the adult survival rate in the 8 EU excommunist countries

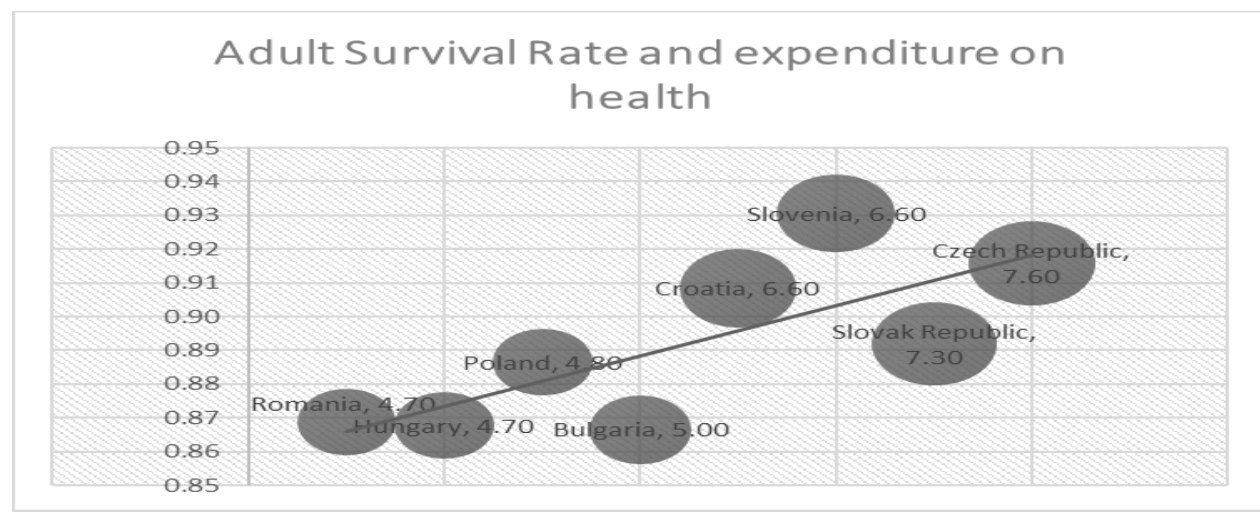

Fig. 5. The relation between public expenditure on healthcare and the adult survival rate in the $8 \mathrm{EU}$ ex-communist countries 
The educational dimension of HCI has 3 pillars. The first one is the expected years of school. It is based on the current enrollment rates in each country and it tells how many years of education a child passing through the current school system expect to obtain. This number of years ranges from 12.9 (Bulgaria) to 13.9 (Czech Republic). We can appreciate that there are not significant differences among the countries from this respect. Moreover, the other two pillars composing the educational dimension are more relevant descriptors of the statues quo of education on the 8 countries.

The second pillar of the educational dimension is harmonized learning outcomes and it refers to the results obtained in the major international testing programs like OECD's PISA and TIMSS. Amon the 8 countries the score of harmonized learning outcomes ranges from 453 (Romania) to 537 (Poland) showing major gaps in the quality of education by contrast with the expected years of school.

When corelating the harmonized test scores with GDP/capita and with the public spending on education, we notice that Romania has, by far, the poorest performance in education relative to its income and allocation on education

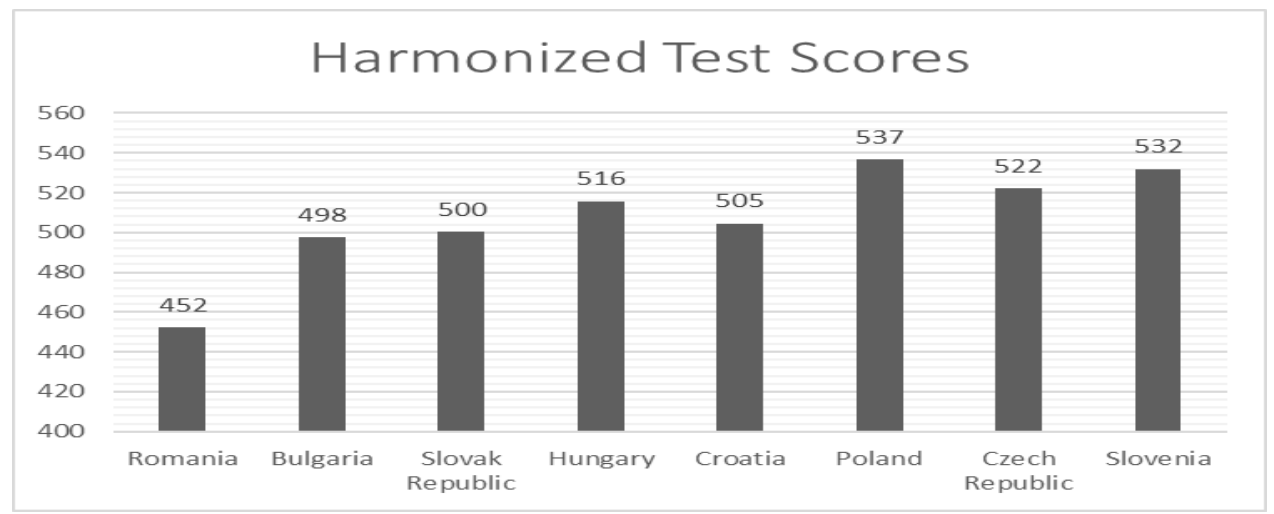

Fig. 6. The harmonized test scores in the $8 \mathrm{EU}$ ex-communist countries

Figures 7 and 8 reveal that Romania struggles not only with low public spending on education, but with ineffective educational policies, system architecture, with low performance in policy implementation and low performance in educational institutions management. The poor harmonized test scores cannot be explained only by Romania's low public spending on education.

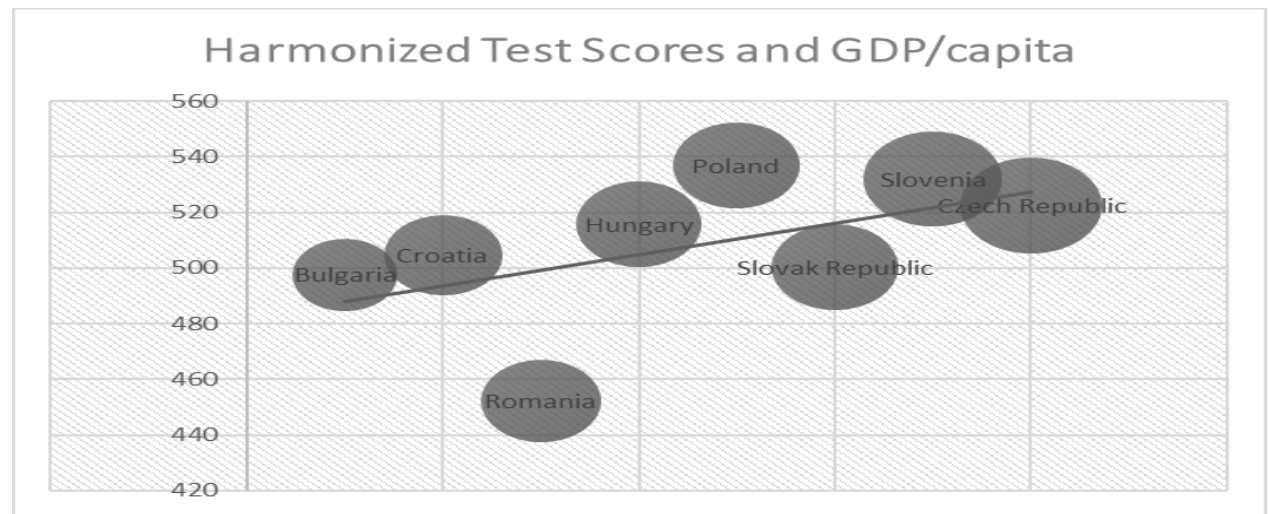

Fig. 7. The relation between GDP/capita and the harmonized test scores in the $8 \mathrm{EU}$ excommunist countries 


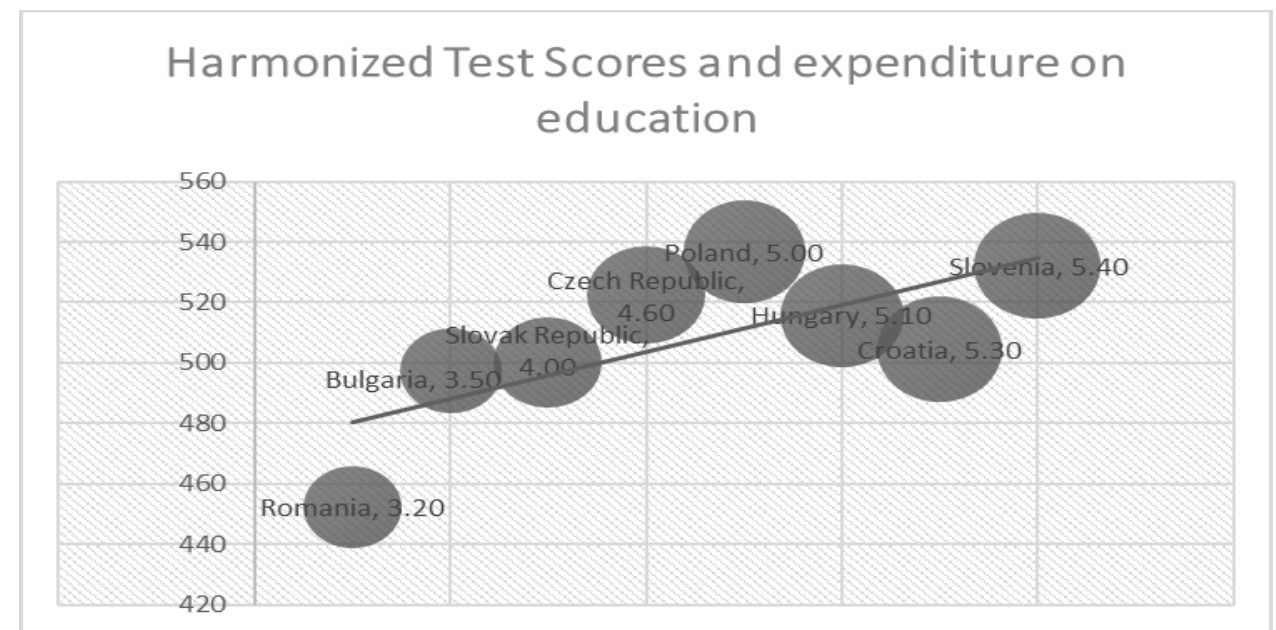

Fig. 8. The relation between the public spending on education and the harmonized test scores in the $8 \mathrm{EU}$ ex-communist countries

The second pillar of the educational dimension is the learning-adjusted years of school. It combines the harmonized test scores with the expected years of school. Using a database containing 160 countries, World Bank researchers found out that each year of school under the age of 18 adds $8 \%$ to the one's productivity in his or her future professional life.

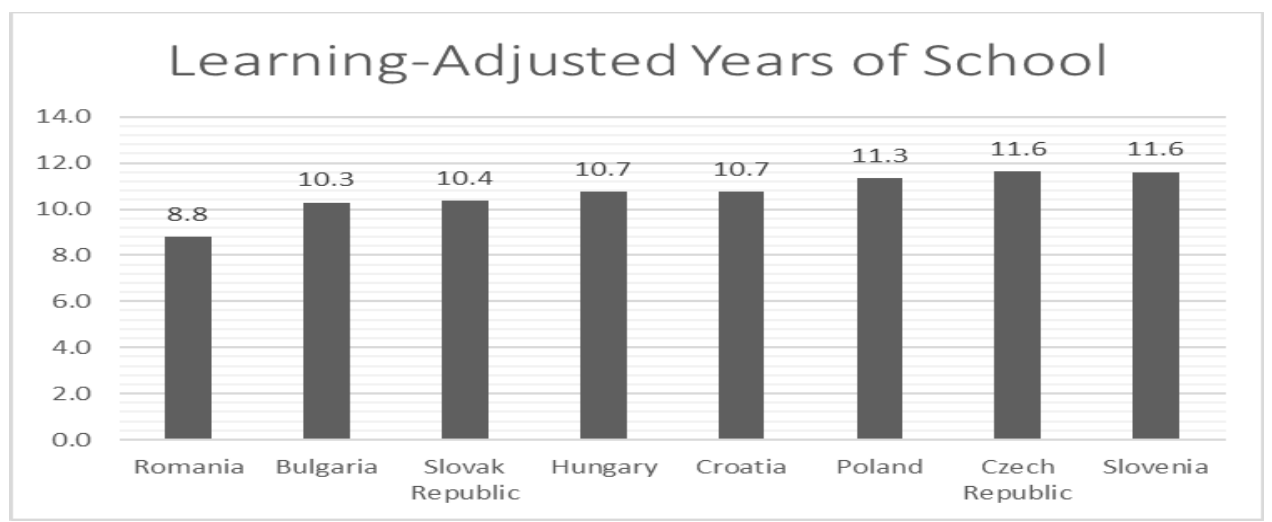

Fig. 8. Learning-adjusted years of school in the $8 \mathrm{EU}$ ex-communist countries

Analyzing figure 8 we can see that a young person educated in Slovenia or Czech Republic is almost 24 percentage points more productive than a person educated in Romania. That is caused mostly by the low quality of education in Romania, not by the expected years of school or by the low public expenditure on education. In Romania, the students spend, on average, 12.2 years in school, but considering their poor performance in the international testing programs, those 12.2 years are the equivalent of 8.8 years of schools in a competitive country.

\section{Discussion and Conclusions}

EU has a highly competitive labor market due to its higher education capabilities training the top professionals worldwide. Some countries have taken advantage of the EU talents brought inside the borders of the Union by the newest member states, while the EU policy in the field of education has encouraged mobilities (exp: through Erasmus Plus Program). In the 8 ex- 
communist EU countries, the migration of human capital to western Europe started in early ' 90 and increased once those countries became EU member state. This is how the accumulation of the human capital in the 8 ex-communist countries was affected by globalization.

Among the 8 countries, building up and strengthening the internal capacity to develop human capital - translated in better healthcare systems and better educational systems - has been more or less a priority. Countries like Slovenia and Czech Republic have built effective healthcare systems to preserve and, to some extent, to enhance the work capacity of the labor. $92-93 \%$ of the population age 15 reach the age of 60 . Similarly, countries like Poland, Czech Republic and Slovenia have succeeded to strengthen their educational systems as part of their transition to the globally opened market economy, to make them competitive at EU level, to retain talents and to increase the labor productivity at national level.

On the opposite, we find Romania that has, by far, the poorest performance in education relative to its income and public spending on education. The educational system is not only underfunded but it is also mismanaged. That is reflected nowadays in the international test scores and in the learning-adjusted years of school where 12.2 years of schools in Romania are the equivalent of 8.8 years of school in a competitive country. On short term, this poor performance makes the Romanian students take advantage of globalization and move for studies (and usually for work after graduation) in the western EU countries. On long term, this poor performance not only limit the future employees to only $60 \%$ of their potential, but also make the talents more likely to leave the country.

Since globalization has brought benefits for other EU ex-communist countries, by pushing them to be more competitive, we consider that on the long run Romania and maybe Bulgaria will benefit as well from this peer pressure created by fellow EU member states.

\section{References}

1. Hendricks, L. (2002). How important is human capital for development? Evidence from immigrant earnings. The American Economic Review, 92(1), 198-219.

2. Becker, G.S. The Age of Human Capital. Retrieved from: https://www.hoover.org/sites/default/files/uploads/documents/0817928928_3.pdf

3. Acemoglu, D., Robinson, J.A. (2012). Why Nations Fail: The Origins of Power, Prosperity and Poverty (1st). 1st ed. New York: Crown, 529.

4. The World Bank. (2019). World Development Report 2019: The Changing Nature of Work. Retrieved from: https://doi.org/10.1596/978-1-4648-1328-3

5. Vaitkevičius, S., Ciutiene, R., meiliene, E., Savaneviciene, A. (2015). Typology of Human Capital Development in EU Countries. Procedia Economics and Finance, 23, $1641-1648$.

6. Bassanini, A., Scarpetta, S. (2001). The Driving Forces of Economic Growth: Panel Data Evidence for the OECD Countries. OECD Economic Studies, 33(2), 9-56.

7. Benhabib, J., Spiegel, M. M. (1994). The Role of human capital in economic development. Evidence from aggregate cross-country time. Journal of Monetary Economics, 34(2), 143-173.

8. Romer, P. M. (1990). Endogenous technological change. Journal of Political Economy, 98(5), part 2, 71-102.

9. Nelson, R .R., Phelps, E. S. (1996). Investment in Humans, Technological Diffusion, and Economic Growth. The American Economic Review, 56(2), 69-82.

10. Funke, M., Strulik, H. (2000). On endogenous growth with physical capital, human capital and product variety, European Economic Review, 44(3), 491-515. 
11. Burlacu, S., Alpopi, C., Mitrită, M., Popescu, M. L. (2019). Sustainable e-Governance and Human Resource Development. European Journal of Sustainable Development, $8(5), 16-20$.

12. Dobre, I., Jianu, I., Bodislav, D. A., Radulescu, C. V., Burlacu, S. (2019). The Implications of Institutional Specificities on the Income Inequalities Drivers in European Union. Economic Computation and Economic Cybernetics Studies and Research, 53(2), 59-76.

13. Negescu, M. D., Burlacu, S., Mitriţă, M., Buzoianu, O. C. A. (2020). Managerial Analysis of Factoring at the International Level. Challenges of the Contemporary Society, 13(1), 99-102.

14. Bran, F., Rădulescu, C. V., Bodislav, D. A., Burlacu, S. (2020). Environmental risks in the context of globalization. Economic Convergence in European Union, 350.

15. Ionita, F., Burlacu, S. (2009). Public Administration from Romania in the Knowledge Society and E-learning. Proceedings of the Fifth" Administration and Public Management" International Conference:" Public Institutions' Capacity to Implement the Administrative Reform Process", Bucharest.

16. Costache, G., Marinas, C. V., Igret, R., Burlacu, S. (2015). Internship in the HR Department - Organizational and Individual Perspectives. Proceedings of the International Management Conference, 9(1), 359-370. Bucharest: Faculty of Management, Academy of Economic Studies.

17. Rădulescu, C. V., Dobrea, R. C., Burlacu, S. (2018). The Business Management of Distress Situations. Proceedings of the 12th International Management Conference Management Perspectives in the Digital Era (pp. 741-747). Bucharest.

18. Bran, F., Alpopi, C., Burlacu, S. (2018). Territorial Development-Disparities between the Developed and the least Developed Areas of Romania. LUMEN Proceedings, 6(1), 146-155.

19. Rădulescu, C. V., Bodislav, D. A., Burlacu, S. (2018). Demographic Explosion and It Governance in Public Institutions. Managerial Challenges of the Contemporary Society. Proceedings, 11(1), 18.

20. Burlacu, S., Profiroiu, A., Vasilache, P. C. (2019). Impact of Demography on the Public Finance of the European Union. Calitatea, 20(2), 136-138.

21. Van Mol C., de Valk H. (2016). Migration and Immigrants in Europe: A Historical and Demographic Perspective. In: Garcés-Mascareñas B., Penninx R. (eds.) Integration Processes and Policies in Europe. IMISCOE Research Series. Cham: Springer.

22. Human Capital Index, The World Bank, Data sets. Retrieved from : https://datacatalog.worldbank.org/dataset/human-capital-index

23. International Comparison Program, World Bank, World Development Indicators database, World Bank, Eurostat-OECD PPP Programme. Retrieved from : https://data.worldbank.org/indicator/NY.GDP.PCAP.PP.CD?end=2018\&locations=ROHU-PL-BG-HR-SI-SK-CZ\&start=1990 